\title{
Effect of Burning Temperature on The Quality of Alternatife Bio-energy from Coffee Waste
}

\author{
VIBIANTI DWI PRATIWI
}

Institut Teknologi Nasional Bandung, Indonesia

Email : vibiantidwi@itenas.ac.id

Received 4 Februari 2020 | Revised 26 Februari 2020 | Accepted 22 Maret 2020

\begin{abstract}
ABSTRAK
Sumber daya energi terbarukan alternatif, seperti biobriket dari biomassa atau limbah organik, dapat menjadi solusi untuk masalah ini. Limbah kopi merupakan limbah yang dihasilkan dalam proses produksi, limbah biomassa ini berpotensi untuk digunakan sebagai bahan baku pembuatan biobriket karena memiliki nilai kalor yang cukup tinggi. Briket arang bio adalah arang gumpalan atau batang yang dibuat dari limbah organik yang telah dicetak sedemikian rupa dengan kekuatan tekanan tertentu dan dicampur dengan bahan perekat seperti tepung tapioka. Tujuan dari penelitian ini adalah untuk mengetahui pengaruh suhu pirolisis dalam produksi briket dari limbah kopi. Suhu pirolisis yang akan digunakan: $200^{\circ} \mathrm{C}, 250^{\circ} \mathrm{C}$, $300^{\circ} \mathrm{C}, 400^{\circ} \mathrm{C}$ dan $500^{\circ} \mathrm{C}$. Selain itu, briket akan terdeteksi kadar air, kadar abu, dan nilai kalor. Briket terbaik dari ampas kopi ditemukan pada suhu pembakaran $300^{\circ} \mathrm{C}$ tanpa perekat dengan nilai kalor 7549,42 kal/gram dan dapat menghasilkan daya listrik sebesar 292,49 W. Namun, briket ini menghasilkan kadar abu tak terduga sebesar 3,7\% yang masih di bawah standar SNI 01-6235-2000.
\end{abstract}

Kata kunci: Bahan Bakar Alternatif, Ampas Kopi, Briket, Pirolisis

\begin{abstract}
Alternative renewable energy resources, such as biobriquette from biomass or organic wastes, can be a solution for this problem. Coffee waste is a waste generated in the production process, this biomass waste is potential to be used as raw material for making biobriquette because it has a high enough calorific value. Bio charcoal briquettes are clots or rods charcoal that made from organic wastes which has been molded in such a way with a certain force of pressure and mixed with adhesive materials such as tapioca starch. The purpose of the study is to determine the effect of pyrolysis temperature in the production of briquettes from coffee waste. Based on several literature studies, the pyrolysis temperatures which are going to be used: $200^{\circ} \mathrm{C}, 250^{\circ} \mathrm{C}, 300^{\circ} \mathrm{C}, 400^{\circ} \mathrm{C}$ and $500^{\circ} \mathrm{C}$. In addition, the briquette will be detected the water content, ash content, and caloric value. The best briquettes from coffee grounds are found at a combustion temperature of $300^{\circ} \mathrm{C}$ without adhesive with a heating value of $7549.42 \mathrm{cal} / \mathrm{gram}$ and can produce electrical power of 292,49 W. However, this briquette produces unexpected ash content of 3.7\% which is still below to SNI 01-6235-2000 standards.
\end{abstract}

Keywords-Alternative Energy, Biofuel, Briquettes, Coffee Waste, Pyrolysis 


\section{INTRODUCTION}

Global energy is increasing significantly and is expected to continue increase every year, this is due to the growth of industrialization in both developed and developing countries (Aprita, 2016). As one of the developing countries, Indonesia has enormous potential resources as a source of renewable energy, where only a small portion is only used. Related to this, the government issued a Kebijakan Energi Nasional (KEN) through PP No. 5 of 2006 as an update to the Kebijaksanaan Umum Bidang Energi (KUBE) in 1998. Indonesia has abundant biomass resources available and it is estimated that biomass resources in Indonesia are capable of producing at least $434.000 \mathrm{GW}$ or equal to 255 million barrels of oil which can subsidize $30 \%$ of petroleum use. Various efforts to save fuel oil are running low.

The alternatives that can be in the form of the use of coal, peat, biomass and others. Briquette is one alternative energy source that can be used to reduce the problem of energy crisis. Biomass waste can be converted into biobriquette and biopelet through simple technology which is cheap and suitable to be managed by small communities or private companies. The agro-industry sector that continues to grow and develop has the potential to produce waste both during the preparation of raw materials and the production process as well as in the processing process. Waste that is not utilized is available in very abundant quantities has a very close relationship with the potential for environmental pollution so that alternative solutions are needed in handling waste. One alternative for utilizing agricultural waste is to make it a biomass briquette to increase the added value of the waste. Biomass is a renewable clean energy source that can significantly help diversify fuel throughout the world (Aprita, 2016). The use of biobriquette as a fuel is one alternative solution to save on fuel oil usage. Biopelet is a solid biomass based fuel with a tubular solid form. The main process used is compression with high temperature and pressure, thus forming a uniform product. Biopelet can be produced easily from wood waste and other biomass materials (Yang, et al., 2005).

Coffee grounds include waste that can become biomass material. Coffee grounds are usually thrown directly into the trash or directly to the ground, this also adds new problems, namely environmental pollution, especially the problem of soil pollution. The availability of sufficiently abundant coffee grounds waste as a result of community activities that love to drink coffee has very good potential to be developed as biomass-based fuels such as the basic material for making briquettes or biopelet. The following diagram is the chemical content of coffee grounds;

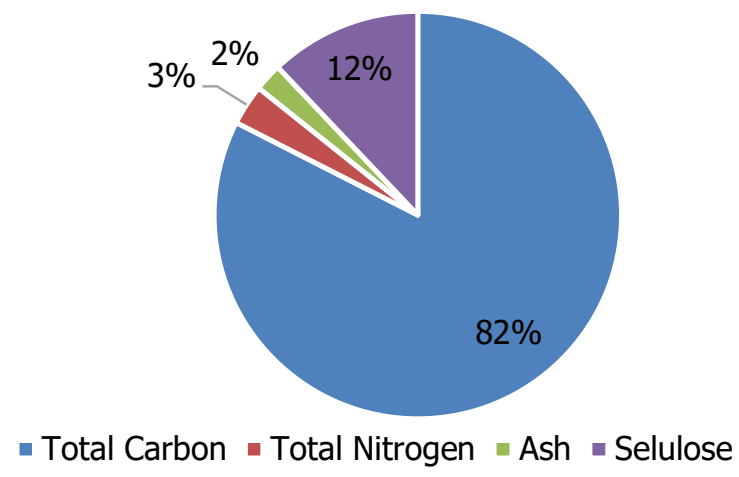

Figure 1. Chemical Content of Coffee Waste

There are three ways in processing briquettes based on heating or combustion, namely carbonization, pyrolysis and torefaction. Carbonization is a method or technology by heating biomass at relatively high temperatures with a limited amount of air or oxygen so that it is 
only sufficient for combustion (Sari \& Paramita, 2007). The natural change of coal, charcoal, briquettes is an important consideration in the carbonization process. This is certainly related to liquid and gas by-products that will be produced. Carbonization temperatures range from $500-1200^{\circ} \mathrm{C}$.

Pyrolysis is the thermal decomposition of biomass that uses heat typically at temperatures of $300-650^{\circ} \mathrm{C}$ and without oxygen. Torrefaction is a method or technology of heating biomass at temperatures between $200-300^{\circ} \mathrm{C}$, at atmospheric pressure without the presence of oxygen. The reaction at this temperature causes the biomass to experience a reduction in water content and loss of fibers in its structure. The optimal length of residence time of the torrefaction process ranges from 30-90 minutes. However, some experiments were made with a short residence time (only a few minutes), but with higher temperatures. Depending on the application, the biomass that has gone through the torrefaction process will be brown or dark brown and will be close to coal. This makes the torrefaction process very superior in the combustion and other gasification processes. Carbonization results to maximize carbon and minimize the hydrocarbon content of solid products. Pyrolysis products to maximize liquid products and minimize charcoal yield, while in torefaction to maximize energy and product yields by reducing the ratio of oxygen to carbon $(\mathrm{O} / \mathrm{C})$ and hydrogen to carbon $(\mathrm{H} / \mathrm{C})$.

Based on several studies in making briquettes, it requires pyrolysis process. Thus, the research in evaluating the effect of pyrolysis temperature in the manufacture of briquettes from coffee grounds is required to determine the quality of the briquettes from coffee grounds. The optimum condition which is shown based on the pyrolysis temperature is expected to be able to produce the quality of briquettes from coffee grounds with a high calorific value as an alternative fuel.

\section{METHOD}

In this research, making the briquette will be carried out use the pyrolysis process. Raw materials used in the form of coffee waste or coffee grounds from stalls or restaurants that provide coffee as the main menu. Coffee waste or ground originating from restaurants or the coffee industry is one of several industrial waste. Coffee waste containing a total carbon of $47,8-58,9 \%$ can be the raw material for making briquettes to become an alternative fuel in the future.

The adhesive material (binder) used is tapioca flour or starch and then printed into a cylindrical shape. The use of tapioca flour as an adhesive (binder) because it has the advantage of smoke produced from burning briquettes is relatively small compared to other adhesive materials, has a small ash content, and can increase the heating value of the briquettes. The cylindrical shape of the briquettes was chosen because it makes it easier in making the briquette process. In addition, this form is very common in the market.

Before pyrolysis, coffee grounds obtained from stalls or restaurants are dried using an oven for 2 hours at a temperature of $105^{\circ} \mathrm{C}$. After drying, the coffee grounds are sieved at $45-20$ mesh. Furthermore, 100 grams of dried coffee grounds mixed with tapioca flour as much as $0 \%, 10 \%$ or $20 \%$ adjust the research variables. After the briquette is molded into a cylindrical shape, it is then burned in a pyrolysis reactor for 90 minutes. Based on several literature studies, the combustion temperature which is the research variable is $200^{\circ} \mathrm{C}, 250^{\circ} \mathrm{C}, 300^{\circ} \mathrm{C}$, $400^{\circ} \mathrm{C}$, and $500^{\circ} \mathrm{C}$. The briquettes that have been burned are weighed and ready to be analyzed. Proximate analysis is a test that includes testing the water content, ash content, 
volatile matter, fixed carbon, and heating value. This proximate analysis is by heating or burning briquettes from coffee grounds.

\subsection{Inherent Moisture}

Testing the water content of the briquettes is done using the gravimetric method. Calculation of the percentage of water content in coffee grounds using the ASTM D-3173 standard with Equation (1).

$$
\% \text { water content }=\frac{a-b}{a} \times 100 \%
$$

where:

$\%$ water content: percentage of water bound in the sample (\%)

$\mathrm{a}=$ Mass sample of initial briquette (gram)

$\mathrm{b}=$ Mass of briquette sample after heating at $105^{\circ} \mathrm{C}$ (gram)

\subsection{Ash Content}

Calculation of the ash content of ash coffee grounds using ASTM D-3174-04 standard with the Equation (2).

$$
\% \text { ash content }=\frac{W_{3}-W_{1}}{W_{2}-W_{1}} \times 100 \%
$$

where :

$\%$ Ash content $=$ percentage of ash in the sample (\%)

$\mathrm{W}_{1}=$ Weight of empty cup (gram)

$\mathrm{W}_{2}=$ Cup weight + sample (gram)

$\mathrm{W}_{3}=$ Cup weight + residue $($ gram $)$

\subsection{Heating Value}

Analysis of the heating value can be done by using a bomb calorimeter to measure the amount of heat released on complete combustion (in excess 02) by briquettes. The working principle of a bomb calorimeter is to conduct electricity in a sample of a briquette attached to a wire (ignition wires) then the length of the wire (ignition wires) which is not burned is measured to obtain a wire correction. The total energy of a material or sample is the amount of heat measured in calories, which is produced when a material or sample is perfectly oxidized in a bomb calorimeter.

\section{DISCUSSION}

Consumption coffee of $70 \%$ in the world comes from Arabica coffee species and $26 \%$ comes from Robusta species. Coffee is a family of the genus Rubiaceae Coffea. There have been 80 species of coffee identified in the world but the coffee that is often produced and consumed by the world community is robusta and arabica coffee (Farah, 2012). Chemical content in coffee is as follows; 
Effect of Burning Temperature on The Quality of Alternatife Bio-energy from Coffee Waste

Table 1. Component of Coffee

\begin{tabular}{|c|c|c|c|c|}
\hline \multirow[b]{2}{*}{ Component } & \multicolumn{2}{|c|}{ Concentration $(\mathrm{g} / \mathbf{1 0 0 g})$} & \multicolumn{2}{|c|}{ Concentration $(\mathrm{g} / \mathbf{1 0 0 g})$} \\
\hline & $\begin{array}{c}\text { Green Coffee } \\
\text { Arabica }\end{array}$ & $\begin{array}{c}\text { Roasted Coffea } \\
\text { Arabica }\end{array}$ & $\begin{array}{c}\text { Green Coffee } \\
\text { Canephora }\end{array}$ & $\begin{array}{c}\text { Roasted Coffee } \\
\text { Canephora }\end{array}$ \\
\hline Sucrose & $6-9$ & $4,2-\operatorname{tr}$ & $0,9-4$ & $1,6-\operatorname{tr}$ \\
\hline Reducing sugar & 0,1 & 0,3 & 0,4 & 0,3 \\
\hline Polysaccharides & $34-44$ & $31-33$ & $48-55$ & 37 \\
\hline Lignin & 3 & 3 & 3 & 3 \\
\hline Pectin & 2 & 2 & 2 & 2 \\
\hline Protein & $10-11$ & $7,5-10$ & $10-11$ & $7,5-1$ \\
\hline Amino Acid & 0,5 & not detected & $0,8-1$ & not detected \\
\hline Kafein & 0,9 & $1,1-1,3$ & $1,5-2,5$ & $2,4-2,5$ \\
\hline Trigonelline & $0,6-2$ & $1,2-0,2$ & $0,6-0,7$ & $0,7-0,3$ \\
\hline Nicotinic Acid & - & $0,016-0,026$ & - & $0,014-0,025$ \\
\hline $\begin{array}{c}\text { Coffee Oil } \\
\text { (triglycerides, } \\
\text { sterol/ } \\
\text { tocopherol) }\end{array}$ & $15-17$ & 17 & $7-10$ & 11 \\
\hline Diterpen & $0,5-1,2$ & 0,9 & $0,2-0,8$ & 0,2 \\
\hline Mineral & $3-4,2$ & 4,5 & $4,4-4,5$ & 47 \\
\hline $\begin{array}{c}\text { Chlorogenat } \\
\text { Acid }\end{array}$ & $4,1-7,9$ & $1,9-2,5$ & $6,1-11,3$ & $3,3-3,8$ \\
\hline Aliphatic Acid & 1 & 1,6 & 1 & 1,6 \\
\hline Quinic Acid & 0,4 & 0,8 & 0,4 & 1,0 \\
\hline Melnoidins & - & 25 & - & 25 \\
\hline
\end{tabular}

Ground coffee is coffee beans that have been roasted, ground or ground to have a smooth shape (Hayati, et al., 2012). The key to the process of producing ground coffee is roasting because it is a step in the formation of distinctive aromas and flavors from the heat-treated coffee beans. Dark roast coffee beans produce darker coffee beans because hydrolyzed compounds are hydrolyzed into carbon elements while sugar compounds undergo caramelization (Khusna \& Susanto, 2015).

A small amount of coffee grounds is used in a small part for animal feed or nutritional enhancements for plants. But in some areas, coffee waste is burnt in the open field or left over can cause both air and soil pollution and become biomass waste that needs to be considered (Hachica, et al., 2012). Coffee grounds have many benefits, especially for plants that can increase the intake of Nitrogen, Phosphorus and Potassium (NPK) which is needed by plants so that they can fertilize the soil. Coffee grounds can be used as an organic fertilizer because they contain minerals, carbohydrates, help releasing nitrogen as plant nutrients, and coffee grounds are acidic thereby reducing soil $\mathrm{pH}$. 
Apart from being a fertilizer, coffee grounds including biomass can be used as fuel. Fuel is a material that when heated at a certain temperature will experience a chemical reaction with oxygen contained in the air and can release heat or energy. A good fuel when burned can continue the combustion process by itself accompanied by the release of carbon (Ndraha, 2009). In this study, coffee grounds will be used as solid fuels. Solid fuels are fuels that are hard and the structure is very tight. Solid fuels have been used for a long time as an energy source that generates heat from the combustion process of solid materials / substances. Solid fuel is the cheapest alternative fuel and is possible to be mass-developed in a relatively short period of time considering the technology and equipment used are relatively simple (Nugraha, 2013).

In this study, coffee grounds are formed into briquettes. Briquette is the process of compressing material with small particle size from organic waste, factory waste, or urban waste into a mold. Briquette is an alternative solid fuel or a subtitution for the cheapest fuel oil and it is possible to be mass-developed in a relatively short time considering the technology and equipment used are relatively simple. The extracting technology used in making coffee grounds is to use low pressure. Binding agents are used to form bonds between biomass particles. With the use of binders, the pressure will be much less when compared to briquettes without using binders. The use of a binder is intended to attract water and form a dense texture or bind the two substrates.

Table 2. Analysis of Tapioca Flour

\begin{tabular}{|c|c|}
\hline Parameter & Value \\
\hline Water (\%) & 9,84 \\
\hline Ash (\%) & 0,36 \\
\hline Fat (\%) & 1,5 \\
\hline Protein (\%) & 2,21 \\
\hline Fiber (\%) & 0,69 \\
\hline Carbon (\%) & 85,2 \\
\hline
\end{tabular}

Tapioca adhesives cause relatively little smoke compared to other adhesives. Tapioca adhesives produce briquettes in low value of density, compressive strength, ash content, and volatile matter. However, it has higher value of water content, carbon content, and heating value. The advantage of tapioca flour adhesive is that it produces high dry adhesion strength. However, this adhesive also has weaknesses, namely low water resistance, susceptible to fungi, bacteria and starch-eating animals (Ndraha, 2009).

In the use of briquettes for alternative fuels usually, need to be printed. Printing aims to obtain a uniform shape and facilitate packaging and use. Printing briquettes will improve the appearance and add economic value. There are various kinds of printing equipment that can be chosen, depending on the intended use, which requires a certain violence or compressive force. In the free market exists various forms of briquettes whose specifications was suitable by the number of industries or businesses and depend on their use (Lubis, 2011).

After printing, coffee grounds briquettes are burned by torrefaction process and pyrolysis process. Torrefaction is a method or technology of heating biomass at temperatures between $200-300^{\circ} \mathrm{C}$, at atmospheric pressure without the presence of oxygen. The reaction at this temperature causes the biomass to experience a reduction in water content and loss of fibers in its structure. The optimal length of the residence time of the torrefaction process ranges from 30-90 minutes. Depending on the application, after experiencing the torrefaction process, 
the biomass will have the brown or dark brown color, which is closed to coal. This makes the torrefaction process very superior in the combustion and other gasification processes. Even torrefaction can improve fuel quality among other fuel treatment processes when combined with densification (Bergman, 2005). While the pyrolysis process is a thermal decomposition of biomass that uses heat usually at temperatures of $300-650^{\circ} \mathrm{C}$ and without oxygen.

In this research, making the briquette will be carried out use the torrefaction and pyrolysis process. Raw materials used in the form of coffee waste or coffee grounds from stalls or restaurants that provide coffee as the main menu. During burning process (torrefaction or pyrolysis process), fuel particles are heated at a rate determined from ambient to maximum temperatures, known as pyrolysis temperatures (Basu, 2010). Pyrolysis temperature affects the composition and yield of the product. Low temperatures produce more charcoal, high temperatures produce less charcoal. The results of the pyrolysis of coffee grounds presented in Table 3.

Table 3. Yield of Charcoal

\begin{tabular}{|c|c|}
\hline $\begin{array}{c}\text { Burning } \\
\text { Temperature } \\
\left({ }^{\circ} \mathbf{C}\right)\end{array}$ & \% Yield \\
\hline $\mathbf{2 0 0}$ & 87,51 \\
\hline $\mathbf{2 5 0}$ & 75,11 \\
\hline $\mathbf{3 0 0}$ & 51,49 \\
\hline $\mathbf{4 0 0}$ & 42,22 \\
\hline $\mathbf{5 0 0}$ & 32,24 \\
\hline
\end{tabular}

The decrease in mass of material caused by heating that causes decomposition of the material or the release of volatile substances or volatile matter. Volatile matter consists of methane, hydrocarbon compounds, nitrogen, and hydrogen. Burning temperature released volatile matter while the carbon remains because carbon will not burn if without oxygen.

In the coffee component, sucrose, polysaccharide, reducing sugars, protein, and pectin will quickly decompose at low temperatures while lignin at high temperatures. Lignin can decompose at temperatures of $250-500^{\circ} \mathrm{C}$ while sucrose, polysaccharide, reducing sugars, proteins, and pectin are simple carbon chains and will immediately decompose at low temperatures. Lignin is a complex polymer (Triono, 2006). As a result of this complexity, lignin is a component of lignocellulose that is difficult to break down. The yield decreases as the burning temperature rises from $200-500^{\circ} \mathrm{C}$. The amount of charcoal produced depends on the burning temperature. Low temperatures produce more charcoal, high temperatures produce less charcoal, this shows that high temperatures cause a lot of loss in the mass of coffee grounds. This is because at higher temperatures it causes a fast decomposition process in hemicellulose because hemicellulose is most unstable with high temperatures (Tjeersma \& Boke, 2006).

Calculation of water content aims to determine the hygroscopic nature of charcoal briquettes. Charcoal is very easy to absorb water or charcoal has high hygroscopic properties. Measurement of water content of charcoal briquettes is done after pressing and drying. Water content in making charcoal briquettes is very influential on the quality of charcoal briquettes. The higher the water content will cause the quality of the charcoal briquettes to decrease, especially it will affect the heating value of the charcoal briquettes and the charcoal briquettes 
will be more difficult to ignite. This is due to the fact that the energy produced will be more absorbed to vaporize the water contained in the charcoal briquettes.

In this study, the manufacture of briquettes from coffee pulp waste was carried out based on variations in pyrolysis temperature and the amount of adhesive used. The following are the results of the measurement of the briquette's water content after the pyrolysis process and the addition of penetration using gravimetric method.

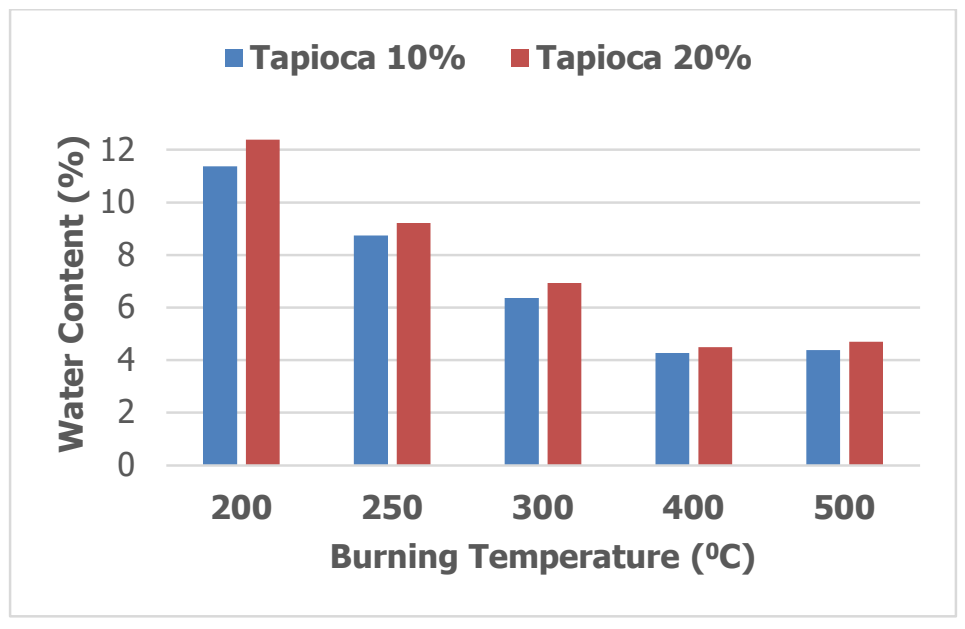

Figure 2. Water Content of Briquette

From the results of this study were obtained based on the pyrolysis temperature used, the largest value of water content was at $200^{\circ} \mathrm{C}$. This is due to the low operating temperature so that the reaction of evaporating water content or so-called dehydration in the material runs slowly, the higher the temperature the lower the water content. However, there was an increase in the water content of the briquettes made at a pyrolysis temperature of $500^{\circ} \mathrm{C}$. This increase in water content can be caused by water content in different biomass. Such deviations can also occur allegedly because when drying using the oven, not all the water contained in the briquettes is evaporated. The unstable temperature of the oven causes the evaporation of water on the briquettes to be uneven. However, the deviated water content in the theory is still standard briquettes according to SNI 01-6235-2000 which is below $8 \%$.

Whereas based on the adhesive composition, the highest moisture content was found in the binder composition $20 \%$ and the lowest was found in the binder composition $10 \%$. This shows a directly proportional relationship between the concentration of the adhesive and the moisture content of the coffee grounds. The results obtained in this study are in accordance with the theory that the higher the binder composition used, the greater the water content of the briquettes. The more adhesives used, the more amount of water is needed to convert tapioca flour to adhesives so that the water content in the briquettes will be large.

In the research (Triono, 2006) said that ash content is a waste material from combustion that has no calorific value or no carbon element anymore. One of the constituent elements of ash is an inorganic component, one of which is silica. Following are the results of the ash content contained in the briquettes from coffee grounds made based on variations in pyrolysis temperature and research composition. 


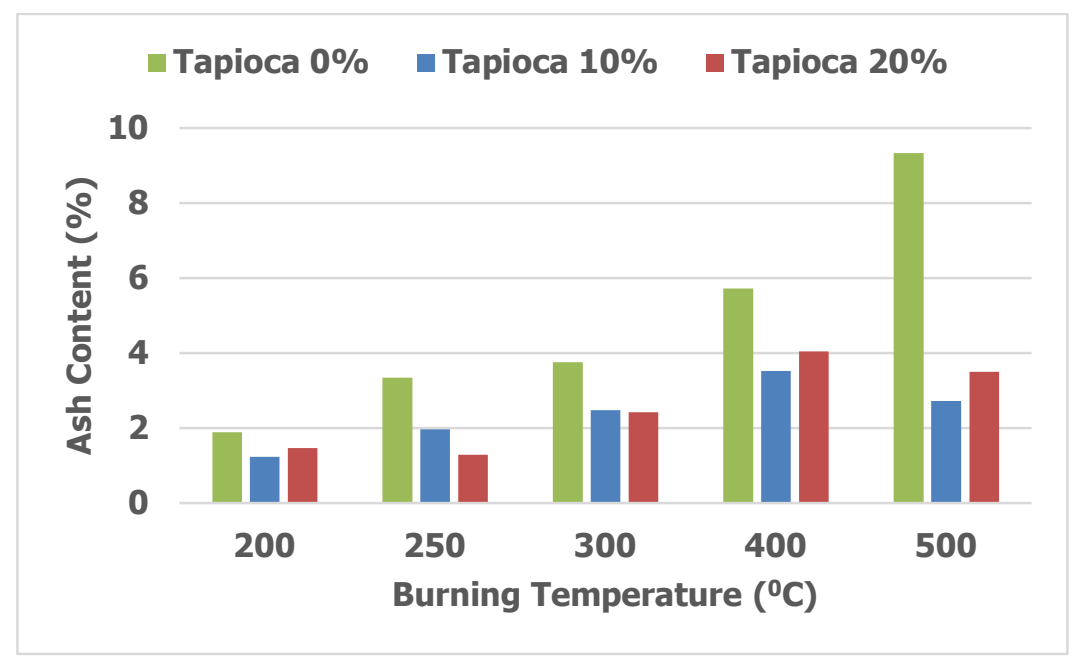

Figure 3. Ash Content of Briquette

The temperature variation treatment has a significant influence on the ash content of the briquettes. When seen from Figure 3, the higher the burning temperature used in the process, the greater the ash content contained in the briquettes. In the research said that the higher the pyrolysis temperature, the higher the ash content produced, as well as the research conducted with increasing pyrolysis temperature, the concentration of inorganic substances increases, in this case, ash. In this study, ash content increased with increasing burning temperature. This is following the theory, but a deviation occurs at a temperature of $500^{\circ} \mathrm{C}$ were at a temperature of $500^{\circ} \mathrm{C}$ the ash content has decreased. A decrease in ash content is likely to occur because when an increase in temperature from $400^{\circ} \mathrm{C}$ to $500^{\circ} \mathrm{C}$, some inorganic substances are evaporated as gases or liquids so that the decrease in ash content occurs when temperatures are high $\left(500^{\circ} \mathrm{C}\right)$. According to SNI 01-6235-2000 standards in (Aprita, 2016), ash content that meets the requirements for fuel is $8 \%$, so the deviation that occurs still meets fuel standards.

When viewed from the amount of adhesive used, Figure 3 states that the higher the amount of adhesive used, the higher the ash content produced. This is because the additives in the form of adhesives and lime already have inorganic components with a percentage of each ash content, which in turn increases the percentage of the ash briquettes themselves. High ash content will cause crust and can reduce the quality of the resulting briquettes caused by a decrease in the heating value and the rate of combustion, but the addition of adhesives needs to be done because if the adhesive is not added, the briquettes will be destroyed or cannot be formed.

Measurement of the heating value aims to determine the heating value of combustion that can produce briquettes. According to the research explained that the heating value is the most important quality parameter for the quality of briquettes as fuel. The higher the heating value of briquette fuel, the better the quality. The following results of the analysis of the heating value of briquettes from coffee grounds. The highest of the heating value from this study at temperature $300^{\circ} \mathrm{C}$ without adhesive about $7549.42 \mathrm{cal} / \mathrm{gram}$. The ability of briquettes as alternative energy can be seen based on the electric power generated. In this study, the highest heating value can produce electrical power of $292,49 \mathrm{~W}$. 


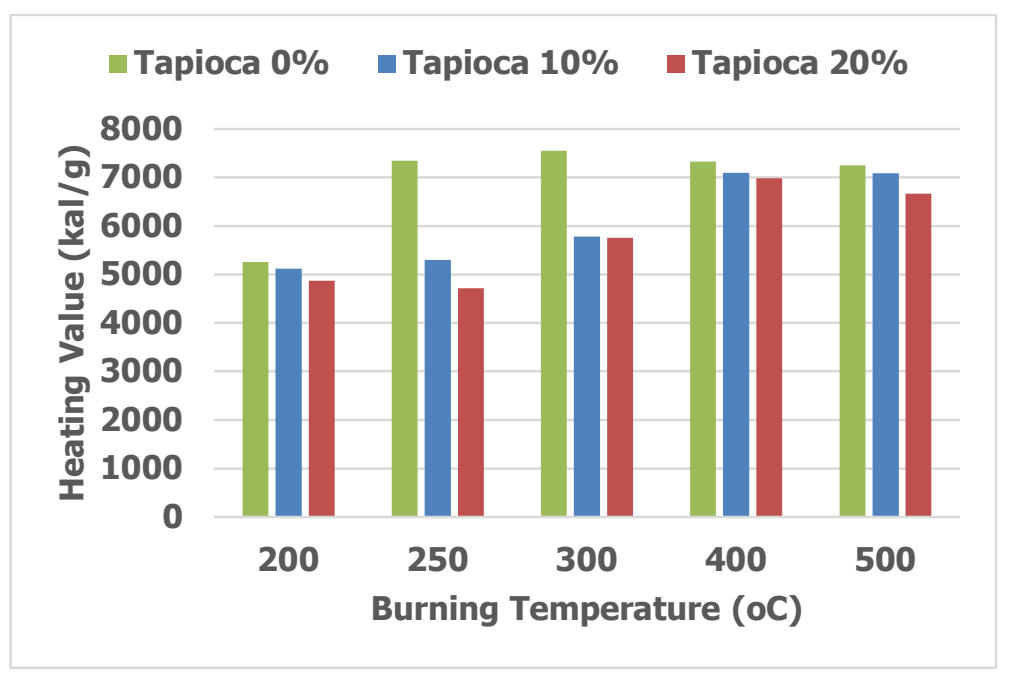

Figure 4. Caloric Value of Briquette

When viewed based on variations in burning temperature according to theory, briquettes with the highest pyrolysis temperatures have the highest heating value. From the results obtained in this study, the higher the temperature used in the pyrolysis process, the greater the calorific value of coffee grounds. This follows the theory, but the decrease in the value of heat energy at $500^{\circ} \mathrm{C}$. This could be caused by several things, including the evaporation of carbon molecules to form ash which will reduce the calories of charcoal due to temperatures that are too high. The heating value is also influenced by water content and charcoal ash content. The higher the water content and ash content, it can reduce the heating value of the charcoal produced (Malaidji, et al., 2018). In the case of preparation and printing of raw materials, besides the pyrolysis tool used at $400^{\circ} \mathrm{C}$ is a tool that has been repaired so that the spread of heat evenly on the system.

Effect of adhesive concentration on the heating value of briquettes from coffee grounds. Where can be seen in Figure 4, it can be seen a decrease in the heating value along with an increase in the concentration of adhesive used, this result is following research conducted which states that a $10 \%$ adhesive concentration produces an optimal heat value. In addition, it can be seen that the decrease in heating value is influenced by the number of coffee grounds that are getting fewer in number, which means that the composition of the briquette material has an influence on the heating value produced. The results of the analysis of variance analysis showed that the composition of the adhesive concentration and the interaction of the two factors had a significant effect on the heating value of the briquettes produced. The difference in the amount of heat value of each treatment is caused by differences in the accumulation of the amount of heat contained in each briquette, which is influenced by the composition of the briquette making material.

From the results obtained, most of the briquettes made in this study belong to the range of heating values determined by SNI 01-6235-2000, which is $>5000 \mathrm{cal} / \mathrm{g}$. However, briquettes made at $200^{\circ} \mathrm{C}$ with $20 \%$ amount of adhesive produce briquettes with a heating value of 4863 $\mathrm{cal} / \mathrm{g}$, this value is not included in the range of heating values specified by SNI 01-6235-2000 so that these briquettes cannot be made as fuel because of small calorific value. As for this experiment, the testing of non-adhesive briquettes and the results of coffee grounds did not have a higher heating value than coffee pulp briquettes with adhesives because of the addition of adhesives also caused the heating value of coffee grounds to decrease because the adhesives had thermoplastic and hard-to-burn properties and carrying more water so that the 
heat generated first is used to evaporate water in the briquette, this is evidenced from the moisture content test which shows that the more adhesive material, the higher the water content.

\section{CONCLUSION}

In this study, it can be concluded that the best briquettes from coffee grounds at a combustion temperature of $300^{\circ} \mathrm{C}$ without adhesive with a heating value of $7549.42 \mathrm{cal} / \mathrm{gram}$ and can produce electrical power of $292,49 \mathrm{~W}$. However, this briquette produces unexpected ash content of $3.7 \%$ which is still below to SNI 01-6235-2000 standards. So, it can be a bioenergy alternative in reducing the need for coal in industrial utilities.

\section{REFERENCES}

Aprita, I. R. (2016). Produksi Biopelet dari Ampas Seduhan dan Cangkang Biji Kopi dengan dan tanpa Pra Perlakuan Bahan pada berbagai Komposisi Perekat. Bogor: Institut Pertanian Bogor.

Basu, P. (2010). Biomass Gasification and pyrolisis. Elsevier Inc.

Bergman, P. (2005). Torrefaction for Biomass Co-firing in Existing Coal-fired Power Stations BIOCOAL. Belanda: Energy Research Centre of Netherlands.

Farah, A. (2012). Coffee: Emerging HEalth Effects and Disease Prevention First Edition. United State of America: Wiley-Blackwell Publishing Ltd.

Hachica, R., Rekik, O., Hachica, S., Ferchichi, M., Woodward, S., Moncef, N., Mechichi, T. (2012). Co-composting of spent coffee ground with olive mill wastewater sludge and poultry manure and effect of Trametes versicolor inoculation on the compost maturity. Chemosphere, 88, 677-682.

Hayati, R., Ainun, M., \& Farnia, R. (2012). Sifat Kimia dan Evaluasi Sensori Bubuk Kopi Arabika. Jurnal Floratek 7, 66-75.

Khusna, D., \& Susanto, J. (2015). Pemanfaatan Limbah Padat Kopi sebagi Bahan Bakar Alternatif dalam Bentuk Bricket Berbasis Biomass (Studi Kasus di PT Santos Jaya Abadi Instant Coffee). Seminar Nasional Sains dan Teknologi Terapan III. Surabaya: Institut Teknologi Adhi Tama Surabaya.

Lubis, H. (2011). Uji Variasi Komposisi Bahan Pembuat Briket Kotoran Sapi dan Limbah Pertanian. Medan: Universitas Sumatera Utama.

Malaidji, E., Anshariah, \& Budiman, A. A. (2018). Analisis Proksimat, Sulfur, Dan Nilai Kalor Dalam Penentuan Kualitas Batubara Di Desa Pattappa Kecamatanpujananting Kabupaten Barru Provinsi Sulawesi Selatan. Jurnal Geomine, 131-137. 
Ndraha, N. (2009). Uji Komposisi Bahan Pembuat Briket Bioarang Tempurung Kelapa dan Serbuk Kayu Terhadap Mutu yang Dihasilkan. Medan: Universitas Sumatera Utara.

Nugraha, J. (2013). Karakteristik Termal Briket Arang Ampas Tebu dengan Variasi Bahan Perekat Lumpur Lapindo. Jember: Universitas Jember.

Sari, E., \& Paramita, S. (2007). Pembuatan Briket dari Sekam Padi Menggunakan Poliethylene sebagai Binder. Bandung: Institut Teknologi Nasional Bandung.

Tjeersma, M. J., \& Boke, B. (2006). Chemical Analysis Of Heat Treated Softwoods. Netherlands: HR Hout Research Wageningen.

Triono, A. (2006). Karakteristik Briket Arang dari Campuran Serbuk Gergajian Kayu Afrika (Maesopsis eminii Engl) dan Sengon (Paraserianthes falcataria L. Nielsen) dengan Penambahan Tempurung Kelapa (Cocos nucifera L). Bogor: Institut Pertanian Bogor.

Yang, Y., Ryu, C., Khor, A., Yates, N., Sharifi, V., \& Swittenbank, J. (2005). Effect of Fuel Properties on Biomass Combustion Part 1. United Kingdom: Sheffield University Waste Incinerator Centre (SUWIC). 